\title{
Rewritten Bible in the "Museum" Slavonic Translation of the Song of Songs
}

\author{
Basil Lourié
}

St. Petersburg, Russia; National Research University Higher School of Economics (HSE)

hieromonk@gmail.com

\section{Summary}

The so-called "Museum" Slavonic translation of the Song of Songs contains a specific recension enrooted in Jewish Second Temple traditions. It becomes more plausible that the Slavonic translation has been produced in the earliest period of Slavic writing directly from Syriac rather than from Hebrew, as it was proposed earlier.

\section{Keywords}

Songs of Songs - Slavonic translations from Syriac - Slavonic Bible - Second Temple Jewish exegesis

Among the Slavonic versions of the Song of Songs, there are two which are now considered as being directly translated from the Hebrew. The later, whose Sitz im Leben is known, is dependent on the earlier. The earlier one remains rather enigmatic and, therefore, is the object of the present study.

Both translations are preserved in the unique manuscripts: the earlier one in the so-called Museum manuscript (= Mus; Russian State Library, coll. 178, Nr 8222; first published by Anatoly Alekseev in 1981 $)^{1}$ and the later one in the Vil-

1 А.А. Алексеев, "Песнь Песней по списку XVI века в переводе с древнееврейского оригинала [The Song of Songs according to a Manuscript of the 16th Century Translated from a Hebrew Original]," Палестинский сборник, 27 (1981), pp. 63-79. Alekseev's actual publication on the topic is ch. 5 “Два древнерусских перевода Песни Песней с еврейского 
nius manuscript (= Vil; F 19-262), ${ }^{2}$ both of the sixteenth century. Both manuscripts are certainly Christian.

The scholarly consensus is that the Vilnius translation is of "West Russian" origin, that is, Ruthenian or Belorussian. ${ }^{3}$ The translation could be either Jewish or Christian. In the latter case, it would have been produced with a help of a Jewish informant or convert. What is important for our study, the Vilnius translation, even though, normally, follows closely the Masoretic Hebrew text, often borrows from the earlier translation. In one place it even repeats a peculiar digression of Mus from the Masoretic text in Cant 1:17 (s. below, section 2.1). The Vilnius translation is roughly dated to a period preceding the date of the manuscript but not very distant one, that is, the late fifteenth or the early sixteenth century.

The West Slavic features are presented in the Museum translation as well. The problem is, however, whether they belong to the original translation or are linguistic deposits accumulated during the textual transmission in the Ruthenian-speaking area. Alekseev and Taube opt for the second alternative, whereas Thomson for the former: "there can be no doubt but that the translation was made in Ruthenia in the fifteenth century."4 This Thomson's conclusion is at odds with his own famous methodological principle that he formulated against Aleksei Ivanovich Sobolevsky (1857-1929): pace Sobolevsky, the lexical features are easily changeable in the literary transmission in Slavonic and, therefore, could never been used as proofs of the origin of the translation itself. ${ }^{5}$ More-

оригинала [Two Old Russian Translations of the Song of Songs from the Hebrew Original]" of his book Песнь Песней в древней славяно-русской письменности [The Song of Songs in the Ancient Slavo-Russian Writing], St. Petersburg, 2002, pp. 137-154, where the text is printed on pp. 144-148.

2 First published as a facsimile in M. Altbauer and M. Taube, The Five Biblical Scrolls in a Sixteenth-Century Jewish Translation into Belorussian (Vilnius Codex 262) (Publications of the Israel Academy of Sciences and Humanities, Section of Humanities), Jerusalem, 1992. Edited by Anatoly Alekseev in Алексеев, Песнь Песней, pp. 149-154.

3 Алексеев, “Песнь Песней," and Алексеев, Песнь Песней; Moshé Taube, "On Two Related Slavic Translations of the Song of Songs," Slavica Hierosolymitana, 7 (1985), pp. 203-209; F.D. Thomson, "The Slavonic Translation of the Old Testament," in: The Interpretation of the Bible: The International Symposium in Slovenia, ed. J. Krašovec (JSOTSup, 289), Sheffield, 1998, pp. 6o5-920, here pp. 874-881.

4 Thomson, "The Slavonic Translation," p. 874 (cf. pp. 873-874).

5 F.D. Thomson, "'Made in Russia': A Survey of the Translations Allegedly Made in Kievan Russia," in: Millennium Russiae Christianae. Tausend Jahre Christliches Russland 988 - 1988: Vorträge des Symposiums anlässlich der Tausendjahrfeier der Christianisierung Russlands (Münster 5.9. Juni 1988), ed. G. Birkfellner (Schriften des Komitees der Bundesrepublik Deutschland zur Förderung der slawischen Studien, 16), Cologne, 1993, pp. 295-354. Repr. as 
over, as Alekseev and Taube have shown, the Slavonic language of the translation is basically (especially on the level of syntax, but also in the lexica) Southern Slavic and not Ruthenian (nevertheless, pace Alekseev, this observation still does not exclude Ruthenian origin but simply increases the comparative likelihood of the alternative hypothesis, that is, that of a non-Ruthenian origin).

According to Taube, however, the South Slavic features "...point rather at the 15th century as the more probable time of translation, if it is assumed to have been made in Russia" (italics mine). Taube implies the epoch of the so-called "Second South Slavic influence" in Russia. ${ }^{7}$ One can feel that he, at least, does not exclude the Ruthenian hypothesis, but his formulation is compatible even with a hypothesis of a South Slavic origin of the translation. Moreover, he gives to understand that, if the origin is not Russian, an earlier date is possible.

Alekseev now (2002) shares Taube's dating (but includes the late 14th cent. as the earliest possible date $)^{8}$, whereas, at first (1981), he localised the translation in the Kievan Rus' that implied the date of the 11th-12th centuries. Alekseev excludes a South Slavic or precisely Bulgarian origin under the pretext that the direct translations from Hebrew in Bulgaria are unknown (argumentum ex silentio). ${ }^{9}$

Alekseev's actual terminus post quem seems to me unjustified. It is based on a hapax legomenon, the Germanic word вирохъ (4:14, rendering ל̦ ל̦ but not

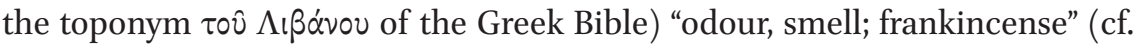
Middle High German wîrouch, wîroch, wyroch etc.). According to Alekseev, this word could have been borrowed though the language of the Ashkenazim Jews

ch. Vwith important Addenda, pages 16-51, in F.D. Thomson, The Reception of Byzantine Culture in Mediaeval Russia (Variorum Collected Studies Series, CS590), Aldershot, 1999.

6 Taube, "Slavic Translations," p. 205.

7 Alekseev was the first who mentioned "the Second South Slavic Influence," when he was still thinking that the translation itself belongs to the Kievan Rus': «...в Муз. замечательно выдержаны орфография II южнославянского влияния, а также церковнославянская морфология в своем русском варианте (...in Mus, the orthography of the Second South Slavic Influence as well as the Church Slavonic morphology are remarkably kept)» (Алексеев, “Песнь Песней," p. 72, cf. pp. 74-76 on the Kievan Rus' as the Sitz im Leben). This is a case when a fact (South Slavic orthography) and an interpretation (Second South Slavic Influence) are confused, as if all other places and epochs where the South Slavic orthography was in use are excluded a priori.

8 Алексеев, Песнь Песней, p. 142.

9 Алексеев, “Песнь Песней," p. 74: «Поскольку ничего не известно о переводах с древнееврейских оригиналов у южных славян... (Because nothing is known on the translations from the Hebrew originals among the South Slavs...)». 
and, therefore, is to be dated to the epoch when the Ashkenazim were settled in the Slavic lands, not earlier than in the fourteenth century. ${ }^{10}$ I do not see any necessity in this recourse to the Jews. The word could be a part of the Ruthenian "linguistic deposits." Middle High German dialects were spoken in relatively large areas of Poland (e.g., one of such dialects resulted into the present Wymysorys, or the Wilamowicean language spoken in the Polish town of Wilamowice in the middle of a Slavic-speaking area, near the Czech and Slovak lands). Wyroch is until now an extremely widespread last name in Poland.

Therefore, neither Alekseev nor Taube provided a convincing terminus post quem.

The Ruthenian hypothesis is the least problematic from the point of view of the presently available knowledge in the history of the texts. Indeed, in Ruthenia, a direct translation from Hebrew would have never been a sensation. All other hypotheses would be, by necessity, in some conflict with the "common knowledge" concerning the lines of textual transmission in Slavonic. Nevertheless, non-Ruthenian hypotheses could better respect the South Slavic features of translation's Slavonic language.

Alekseev considers the earlier translation to be Jewish and proposed for synagogal usage. According to his hypothesis, a number of Slavic biblical translations were either adapted or created by Russian Jews for their synagogal liturgy in Slavonic. ${ }^{11}$

So far, nobody has brought into question that the Hebrew original of Mus was the known Masoretic text. It is this opinion that I would like to challenge now. I will try to show that the original text contained substantial discrepancies with both Hebrew and Greek known texts of the Song of Songs. These discrepancies are certainly Jewish and fitting without problems with Second Temple Judaism(s), where the Song of Songs was considered as a midrash-like reading accompanying the book of Exodus. ${ }^{12}$ The Slavonic translation looks as a targumic elaboration on the original Hebrew text. Needless to say, however,

10 Алексеев, Песнь Песней, р. 142.

11 Алексеев, Песнь Песней, pp. 142-143. The most recent Alekseev's explanation of his ideas on Church Slavonic as a liturgical language of the Jews living in Rus' is available in А.А. Алексеев, “Русско-еврейские литературные связи Киевской эпохи. Результаты и перспективы исследования [A.A. Alekseev, "The Russian-Jewish Literary Connexions in the Kievan Epoch. Results and Perspectives of the Study]," Jews and Slavs, 24 (2014), pp. 167-182. Some of my criticisms are in B. Lourié, "Direct Translations into Slavonic from

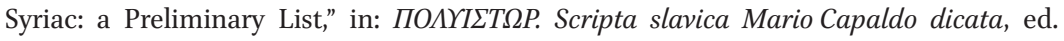
C. Diddi, Moscow, 2015, pp. 161-168. erature), Bloomington, 1990, pp. 106-116 et passim. 
that the extremely elaborated rabbinic Targum of the Song of Songs has no textual intersections with our Slavonic text. We are dealing, in the latter case, with a text lost from the rabbinic tradition, which was a usual fate of "rewritten Bible" texts.

Moreover, I will argue that there is no specific linguistic or philological grounds for postulating Hebrew as the original language of the Slavonic translation. Syriac is a no less fitting option that would agree with my considerations about the Syriac impact on the earliest Slavonic writing, which I have developed elsewhere.

We have to consider four peculiar readings of the Museum translation. This is a substantial number for a relatively short book, which became even shorter due to the lacunae (missing are 5:15b-6:8a, 3:2, and the beginning of 7:1).

\subsection{Cant 1:17: "Boxtree" Instead of "Cypress"}

In 1:17, Vil repeats Mus, and both are going away from both Hebrew ${ }^{13}$ and Greek $^{14}$ known texts (s. Table 1). "Other Slavonic" means here a text close or identical to that of the Elizabeth Bible (1751; the actual standard Bible in Slavonic), which, for the Song of Songs, goes back to the Ostrog Bible (1581); it is provided only as an example of rendering the Septuagint text in Slavonic, in order to facilitate the comparison for the readers familiar with the Slavonic Bible.

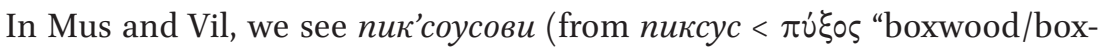
tree") "(made) of boxwood" instead of expected "of cypress."

13 Quoted according to the recent critical edition by Piet B. Dirksen in BHQ, fasc. 18: General Introduction and Megilloth, eds. P.B. Dirksen et al., Stuttgart, 2004, pp. 11-24. Other books of the Hebrew Bible, for lack of their BHQ edition, will be quoted according to BHs.

14 The Song of Songs volume in the Göttingen Septuagint is still in preparation. Therefore, I have used the list of variant readings (including those from the other than LXx Greek translations and Latin translations) in the unpublished dissertation by J.C. Treat, Lost Keys: Text and Interpretation in Old Greek "Song of Songs" and Its Earliest Manuscript Witnesses, Ph.D. diss., The University of Pennsylvania, 1996. I have used as well the apparatus in F. Field, Origenis Hexaplorum quae supersunt. 2nd ed., 2 vols., Oxford, 1875, vol. 2, pp. 411-424, which includes the readings of the Syriac Harqleian version (which is a literal translation from Greek; no critical edition so far). 


\begin{tabular}{|c|c|c|c|c|}
\hline Mus & Vil & Other Slavonic & MT & $\mathbf{L X X}$ \\
\hline <с>тьны домовь & стьны домов & преклади дому & 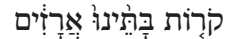 & Soxoi olkwv \\
\hline нашь кедровы, & наших цедровы, & нашего & 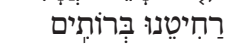 & 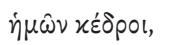 \\
\hline латы наше & латы наши & кедровии, дски & & $\varphi \alpha \tau \nu \omega \dot{\mu} \mu \alpha \alpha$ \\
\hline ник'соусови [read & пискусовы [read & наши & & $\dot{\eta} \mu \hat{\omega} \nu$ \\
\hline пик'соусови] & пик'соусови] & кипарисныя & & 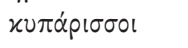 \\
\hline \multirow{5}{*}{$\begin{array}{l}\text { the walls of our } \\
\text { houses are of } \\
\text { cedar, our boards } \\
\text { are of boxwood }\end{array}$} & the walls of our & the beams of our & the beams/rafters & the beams of \\
\hline & houses are of & houses are of & of our houses are & our houses are \\
\hline & cedar, our & cedar, our & cedars, our & cedars, our \\
\hline & boards are of & boards are of & rafters/boards are & ceiling rafters \\
\hline & boxwood & cypress & cypresses/firs & are cypresses \\
\hline
\end{tabular}

This does not conform with the other known recensions of the Song of Songs, including rabbinic Aramaic ${ }^{15}$ and Syriac ${ }^{16}$ ones. However, in the traditional Jewish exegesis, "our house" here is the eschatological temple, ${ }^{17}$ and the traditional description of the species of wood used in this temple is that of Isa-

15 The rabbinic Targum of Song of Songs (commonly dated to the 8th cent. CE) contains almost uninterrupted midrashic digressions. The text survived in two recensions, Eastern and Western. There is no critical edition, but Ph. S. Alexander, The Targum of Canticles (The Aramaic Bible, 17A), Edinburgh, 2003, provided an eclectic translation taking into account the variant readings of both recensions. The most accessible is the electronic edition of the Comprehensive Aramaic Lexicon Project $<$ http://call.cn.huc.edu $>$. There are scholarly editions of both recensions but only that of the Eastern one was available to me: R. Hai Melamed, "The Targum to Canticles According to Six Yemen Mss. Compared with the 'Textus Receptus' (Ed. de Lagarde)," JQR, NS, 10 (1919-20), pp. 377-410, 11 (1920-21), pp. 1-20, and 12 (1921-22), pp. 57-117 (also in a separate edition from the off-prints); there is an English translation of this edition by J.C. Treat, The Aramaic Targum to Song of Songs, published electronically on his personal page at the University of Pennsylvania: <http:// ccat.sas.upenn.edu/ jtreat/song/targum $>$.

16 Critical edition of the Peshitta version: J.A. Emerton and D.J. Lane, "Songs of Songs," in: Vetus Testamentum Syriace iuxta simplicem syrorum versionem, ed. Institutum Peshittonianum Leidense, pars II, fasc. v, Leiden, 1979 (separate pagination).

17 Cf. in Tg. Cant: "Solomon, the prophet, said: 'How fair is the Temple of the Lord that has been built from cedar-wood, but fairer still shall be the Temple that is going to be built in the days of King Messiah, the beams of which will be of cedars from the Garden of Eden, and the joists will be of cypress, teak, and cedar"' (Alexander, Targum of Canticles, p. 95). 
iah 60:13, but only in the Hebrew Bible and not in the Septuagint:18 "The glory of Lebanon shall come to you, the cypress, the elm (?), and the boxtree

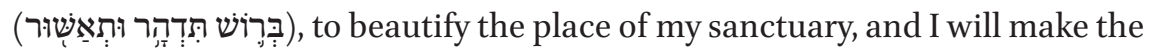
place of my feet glorious"; the same in the rabbinic Aramaic Targum: "the

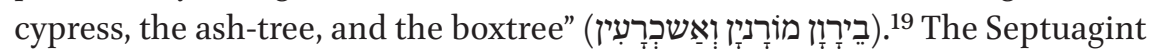
has here "cypress, and pine, and cedar" with no mention of boxtree.

The phrase "cedar and boxtree" occurs exactly in this form in a symbolical indication of the same eschatological temple in the wilderness in Isaiah 41:19, when different kinds of wood are enumerated, but not in the same order in all versions. The phrase $x \varepsilon \dot{\delta} \rho \circ \nu$ xai $\pi \cup \dot{\xi} \circ \nu$ is shared by the Septuagint (and the Syriac Bible Peshițta) with Symmachus; the latter fact testifies its presence in some recensions of the Hebrew Bible in the second century AD. The Hebrew text is more often translated as, e.g., "I will set junipers in the wasteland, the fir and the cypress together" (NIV), with תְִּ understood as "cypress", whereas the same word could be translated as "boxtree" (e.g., among others, in KJV).

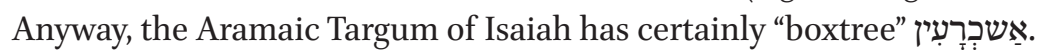

The plural form "houses" instead of the unique "house" (viz. the unique eschatological temple of the New Exodus prophesied by Isaiah) in Mus and Vil looks strange and does not fit with the general symbolical meaning of the verse 1:17. Probably, this is a mistake that appeared in the textual transmission in the Slavic or any other milieu, where the scribes have lost the symbolical meaning of the text (identification of "our house" with the Temple): the plural pronoun "our" would require the plural for "houses".

The setting of the Song of Songs in the Exodus context in both Jewish and Christian traditions is a sufficient reason for considering these parallels as a deliberate reference to the eschatological Exodus by Isaiah.

Cant 2:11-13 is the only passage of the book where its setting in the liturgical calendar becomes explicit: the early spring - which is the time of the Passover. The verse 2:12 in Mus contains a peculiarity: година славим "the time / hour of slavim."

The Hebrew has wַת הָזְמִמיר whe allows two readings: either "time of pruning $[s c$., of vines]" = the first harvest or "time of signing". Vil, together with

The LXX and other Greek translations of Isaiah are quoted according to J. Ziegler, Isaias (Septuaginta: Vetus Testamentum Graecum, 14), Göttingen, 1939.

19 The rabbinic Targum Pseudo-Jonathan of Isaiah is quoted here according to the most comprehensive edition, which is the electronic edition of the Comprehensive Aramaic Lexicon Project $<$ http://calı.cn.huc.edu $>$. 
other Slavonic translations, chose "harvest" (час жатвы). The Septuagint

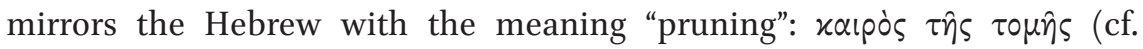

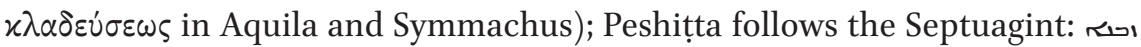
(x). (x) Re Aramaic Targum strays so far from the Hebrew text that it contains no direct equivalent of the Hebrew phrase; nevertheless, it elaborates on Passover topics, especially the slaying of the first-borns. ${ }^{20}$

There are two suppositions on the meaning of the mysterious slavim, both by Anatoly Alekseev: ${ }^{21}$ either Gen. pl. of the hypothetical word * slavima "song" or the hypothetical form (Gen. pl.) of the real word slavii "nightingale." Both hypotheses are incompatible with the known facts of Slavic languages and appear as a kind of "popular etymology" invented ad hoc.

In my opinion, slavim is a rare but really attested to plural form of the Hebrew word שָָׁׁ "quail(s)" used for both singular and collective plural. The plu-

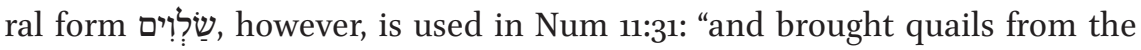
sea." Its ideal Slavonic transliteration would look as *salvim, but the actual slavim fits perfectly with the unvocalised Hebrew original. This rare form of the plural does not occur except Num 11:31 (even in the next verse, Num 11:32, the regular form of the collective plural is used). Therefore, it is very likely that it was not recognised by the translator of our text, whose competence is already questioned by modern scholars. ${ }^{22}$

Once more the Exodus imagery reappears. Notice that the episode with quails is highly important for the Jewish Merkabah mysticism tradition, which is directly referred to in our Slavonic text in 3:10 (s. next section): "the wind of quails" is one of the winds produced by the wings of the Metatron

Tg. Cant 2:12: "And Moses and Aaron (who are likened to palm branches) have appeared to perform miracles (נינ) [sounds like "blossom" > $>$ ('translator's note] in the land of Egypt. The time has arrived for the slaying of the firstborn" (tr. by J.C. Treat here and below). In the commentary to the next verse (2:13), the Targum elaborates on the topic of singing as well, with no direct connexion to the verse commented: "The Assembly of Israel (likened to the first fruits of the figs) opened her mouth and sang the Song at the Reed Sea. Even youths and sucklings praised the Lord of the World with their tongue [cf. Ps 8:2]."

21 Алексеев, Песнь Песней, р. 139.

22 Taube, "Slavic Translations," p. 204: “The many erroneous renderings of Hebrew grammar (there are over forty of them ...), even more than the numerous lexical mistranslations (some of which he [Alekseev] does mention) support Alekseev's assumption that Mus. was translated by a Slav who was not proficient in the Hebrew language." There is a need to notice, however, that the alleged mistranslations reported by Alekseev, according to the present author, are not mistranslations at all, whereas Taube adds no more example. Therefore, there will be a reason for improving this impression of translator's ability. 
according to 3 Enoch 23:4. In the verse 2:12, the mention of quails results in parallelism with the further mention of turtledove ("the time of quails has

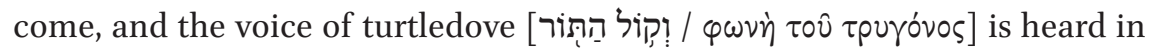
our land").

Quails are a symbol of erotic and especially sinful desire, ह̇ $\pi \imath v \mu i \alpha$ in Hellenistic Jewish Greek. The "time of quails" could be understood as referring to a special time of day, evening (in accordance with Ex 16:13 "about at evening that the quails came"). As the Hellenistic Jewish Book of Wisdom ${ }^{23}$ says, "Afterward they saw also a new kind of birds, when desire led them to ask for luxurious food; for, to give them relief, quails came up from the sea" (Wis

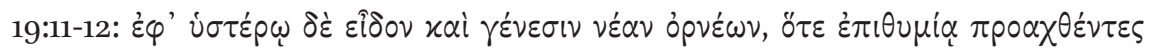

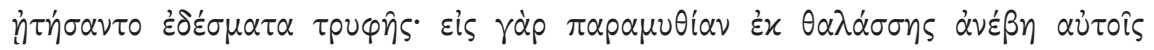

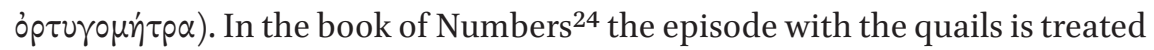
in the same manner: "And he called the name of that place Kibrothhattaavah

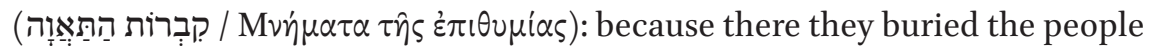

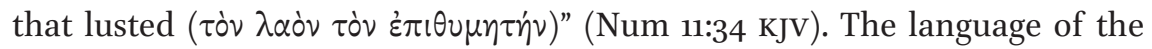
Septuagint is even more specific than that of the Hebrew Bible: the latter mentions "sin" in general, whereas the former "(sexual) desire".

The topic is continued by the Christian exegesis with Paul: "Nevertheless, God was not pleased with most of them, and they were struck down in the wilderness. Now these things occurred as examples for us, so that we might

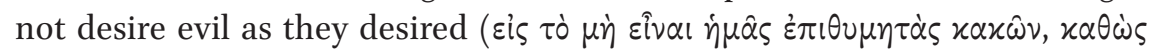

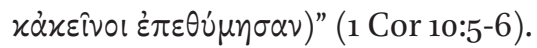

The turtledoves in Cant 2:12 are mentioned immediately after the word rendered in Mus as slavim. The Hebrew Bible reads at this place "the voice of the turtledove is heard in our land." In the immediate context of Song of Songs, a mention of turtledove refers to 1:10, where Mus provides the same translation as the Septuagint: "your jaws are beautiful as turtledoves" ( $\tau i$

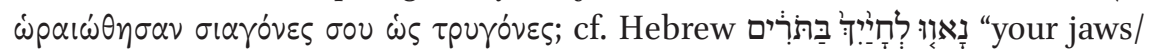

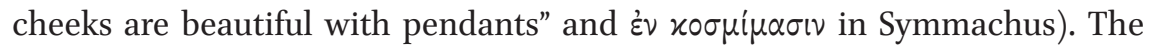
תור translators of the Septuagint and Mus chose the homonymic meaning of "turtledove" instead of the most obvious meaning "pendant" (or another kind of ornament), which is chosen by Symmachus.

The translation of Mus is here even more consequent than that of the Sep-

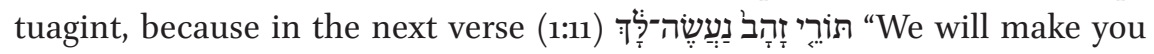

\footnotetext{
23 Quoted according to J. Ziegler, Sapientia Solomonis (Septuaginta: Vetus Testamentum Graecum, 12, 1), Göttingen, 1962.

24 The Greek text is quoted according to J.W. Wevers, Numeri (Septuaginta: Vetus Testamentum Graecum, 3, 1), Göttingen, 1982.
} 
plaits/circlets of gold," where another derivate of the same root is used, and

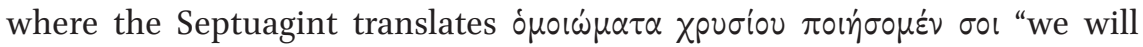
make you images of gold," 25 Mus has горлиць ${ }^{26}$ златыя сътворим тебъ “we will make you (two) golden turtledoves." Given these readings, in Mus, in the verses 1:10 and 1:11, we have to conclude that, in 1:10, the translator understood

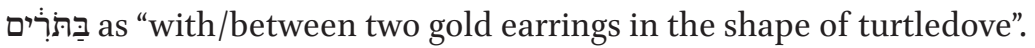

In such a context, "the voice of a turtledove" in 2:12 recalls the voice of the bride. The meaning of the Hebrew homonym in 2:12 has predefined its understanding and translation in 1:10 and 1:11. This explanation is applicable also to Cant 1:10 LXX.

\subsection{The Temple of Solomon and the Merkabah in Cant 3:9-10}

Cant 3:9-10 is an extremely important text in the history of the Jewish exegetical tradition. No wonder that the modern Slavists, without knowing the history of the exegesis, have found here a number of "errors" in both Mus and Vil (s. Table 2).

In 3:9, the word both translators." 27 In fact, "palace" in Vil is one of the two possible - but wrongly chosen - translations of the Aramaic היכל. In Mus, "steps" seem to be

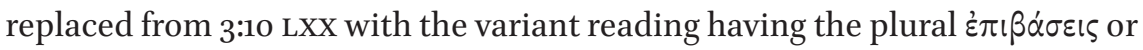
its Hebrew original, if there was one. If, however, in 3:9 Mus the plural въсходы is an erroneous reading instead of the singular въсходъ - which is very likely due to the poor quality of the textual transmission and the similarity between the Cyrillic letters $b$ and $z$ - the meaning becomes much clearer: the calque of a noun with the root $r k b$ "to mount" and the meaning "chariot." Compare, in 3:10 LXx, દ่ $\pi$ i $\beta \alpha \sigma \iota \varsigma$ as a rendering of merkabah, and, in Ps 103:3

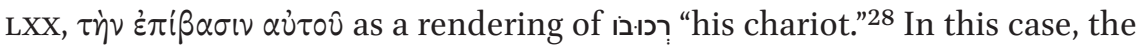
content of the verse 3:9 would be in conformity with that of 3:10. This understanding is corroborated with one of the three Syriac variant readings,

25 Translation by J.C. Treat in A New English Translation of the Septuagint and the Other Greek Translations Traditionally Included under That Title, eds. A. Pietersma and B.G. Wright, Oxford, 2007, p. 662.

26 Here the conjecture by Alekseev горлиц' instead of горниць "(two) upper-rooms" in the manuscript is quite justified.

27 Алексеев, Песнь Песней, р. 139: “затруднило обоих переводчиков.”

28 The dictionaries of the Septuagint Greek do not provide the meaning "chariot" for Cant 3:10 and Ps 103:3. Cf. T. Muraoka, A Greek-English Lexicon of the Septuagint, Louvain, 2009, p. 268: "that which one stands on: 'steps"; J. Lust et al., A Greek-English Lexicon of the Septuagint. Revised ed., Stuttgart, 2003 (electronic book, no page numbers): "means of approach, access Ps 103 (104), 3; steps Ct 3, 10." 
TABLE 2

\begin{tabular}{|c|c|c|c|c|c|}
\hline Hebrew & Aramaic Targum & Greek & Peshițta & Mus & Vil \\
\hline 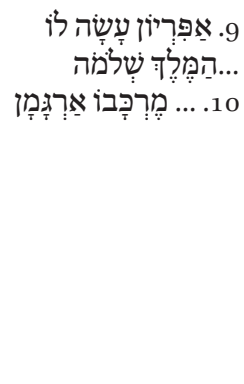 & 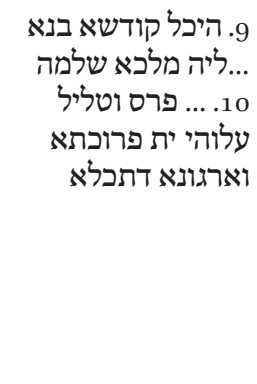 & 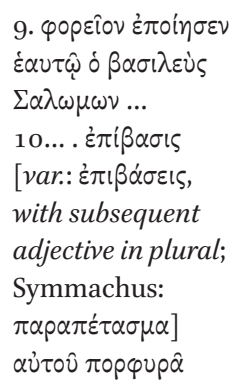 & 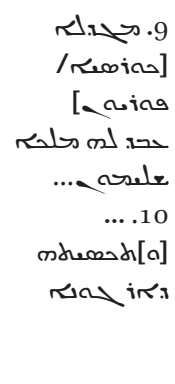 & $\begin{array}{l}\text { 9. въсходы } \\
\text { сътворил к } \\
\text { нему царь } \\
\text { Соломон ... } \\
1 \text {..... и } \\
\text { колесница } \\
\text { его } \\
\text { багрова }\end{array}$ & $\begin{array}{l}\text { 9. палаць } \\
\text { оучинил собъ } \\
\text { царь Соломон } \\
\text {... } \\
\text { 10. ... а покльт } \\
\text { багряныи }\end{array}$ \\
\hline 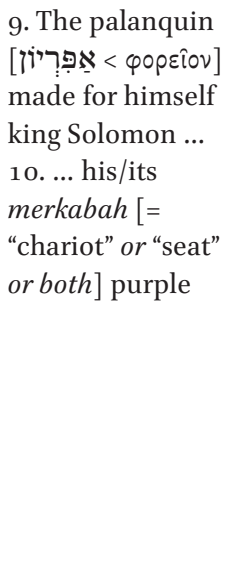 & $\begin{array}{l}\text { 9. The holy Temple } \\
\text { [לכ means either } \\
\text { "temple" or } \\
\text { "palace"] built for } \\
\text { himself king } \\
\text { Solomon ... } \\
\text { 10.... And he } \\
\text { spread out and } \\
\text { draped over it the } \\
\text { curtain of blue } \\
\text { and purple [Ex } \\
36: 35 ; 2 \text { Chr } 3: 14]\end{array}$ & $\begin{array}{l}\text { 9. The palanquin } \\
\text { made for himself } \\
\text { king Solomon ... } \\
\text { 1o.... its step [lit. } \\
\text { ascension; } \\
\text { possible meaning } \\
\text { chariot; var. steps; } \\
\text { Symmachus } \\
\text { curtain] purple }\end{array}$ & 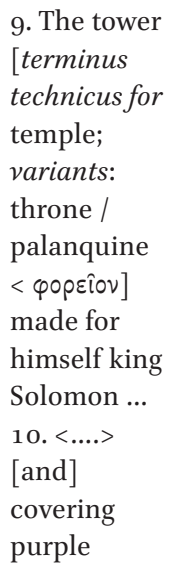 & $\begin{array}{l}\text { 9. The steps } \\
\text { made for } \\
\text { himself } \\
\text { [sc., iל } \\
\text { literally } \\
\text { translated }] \\
\text { king } \\
\text { Solomon ... } \\
\text { 10.... and } \\
\text { his/its } \\
\text { chariot } \\
\text { purple }\end{array}$ & $\begin{array}{l}\text { 9. The palace } \\
\text { created to him } \\
\text { king Solomon } \\
\ldots \\
10 \ldots \text {. and } \\
\text { baldachin/ } \\
\text { curtain purple }\end{array}$ \\
\hline
\end{tabular}

"throne, seat," viz. "throne of Solomon" according to the literal meaning but referring to the image of the throne of God. This Syriac word could have been a rendering of merkabah or another derivate from the root $r k b$ with the meaning of either "throne" or "chariot" or both.

It seems that the verse 3:9 in Mus goes back to an original different from all recensions known to us, where the word אַפְּר wa was replaced with a derivate of the root $r k b$. The same reading reached us through one of the variants of Peshița.

In Cant 3:10, Vil follows the Targum, the Hebrew original of Symmachus, and the Hebrew original of Peshitta in choosing "covering/curtain" instead of "seat/chariot". This is the mainstream tradition of the Jewish exegesis considering this place as referring to the curtain of the Temple of Solomon.

Mus follows another line of the Jewish exegesis. Francis Thomson enumerated the reading "chariot" instead of "seat" in 3:10 Mus as the first among the 
"risible" mistakes of the translation (the second one is "turtledoves" in 1:10, s. above).$^{29}$ In fact, his remark shows this unique thing: philological training without knowledge of the exegesis is not sufficient for evaluating the quality of mediaeval biblical translations.

The late antique Midrash Shir ha-Shirim Rabbah provides no less than five interpretations of the place we are investigating. ${ }^{30}$ The first three are referring to the curtain, the last two (both in ch. III, 23) to the root $r k b$ and the topics related to the chariot. It is worth noting that there is no interpretation related to a "stationary" seate/throne.

The fourth and the fifth midrashic interpretations refer to the chariot of God implicitly through a verb derived from the root $r k b$ : "THE SEAT/CHARIOT OF IT/HIM OF PURPLE: as it says, He rides (רוכב, cf. $\delta$ ह่ $\pi$ i $\beta \alpha i v \omega \nu$ LXX) the heavens to your help (Deut 33:26)" and "THE SEAT/CHARIOT OF IT/HIM OF PURPLE:

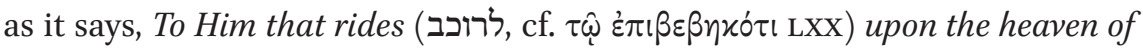
heavens, which are of old (Ps 68:34 MT)." Both Deut 33:26 and Ps 68:34 exclude interpretation of the merkabah in Cant 3:10 as an immobile seat and both of them require its understating as a chariot.

An explicit interpretation of "chariot" in Cant 3:10 is preserved in the 13thcentury midrashic commentary on Deuteronomy, Be-Midbar Rabbah 12:4 (this part is composed in the 11th cent.): "He [king Solomon] made for himself a palanquin of wood from Lebanon. He made ... its chariot of purple. This is the sun which is situated above and rides in its chariot (רוכב במרכבה) and illuminates the world. As it says [Ps 19:6], [He placed in them a tent for the sun] who is like a groom coming forth from the chamber, etc. And because of the power of the sun, the rains fall, and from the power of the sun, the earth yields fruit." ${ }^{31}$

The same tradition, without an explicit reference to the Song of Songs, is preserved in the eighth- or ninth-century Pirke de-Rabbi Eliezer 6: "And the sun rides in its chariot (רוכב במרכבה) and rises crowned like a groom and like $a$ hero, eager to run his course. As it says [Ps 19:6], who is like a groom coming forth from the chamber, like a hero, eager to run his course." ${ }^{32}$

These midrashic interpretations are now connected with the fifth- and sixth-century mosaic pavements in seven Palestinian synagogues excavated

29 Thomson, "The Slavonic Translation," p. 874.

30 These midrashic accounts are studied (and quoted in full) in the unpublished thesis by P.R. Junkermann, The Relationship between Targum Song of Songs and Midrash Rabbah Song of Songs, Ph.D. diss., Manchester: The University of Manchester, 2010, 2 vols.

$3^{1} \quad$ Translation by S.S. Miller, "Epigraphical' Rabbis, Helios, and Psalm 19: Were the Synagogues of Archaeology and the Synagogues of the Sages One and the Same?," JQR, 94 (2004), pp. 27-76, here p. 53, who also quotes the original in the Vilna edition. Translation by Miller, “Epigraphical' Rabbis," p. 54, quoting Higger's ed. 
since 1921, where the chariot of Helios / Sun with four horses is placed in the centre of the twelve signs of Zodiac. ${ }^{33}$ I would like to add some arguments to those of the art historians who, following the intuition of E.R. Goodenough, argued that this composition is related to the prominent place of the sun in some Jewish Second Temple traditions, where the chariot of the sun is either a symbol of $\mathrm{God}^{34}$ (as it is in 3 Baruch) or belongs to a divinised human figure such as Enoch-Metatron ${ }^{35}$ (as it is in 2 Enoch) or Joseph (Joseph and Aseneth). ${ }^{36}$

\section{The Title of the Slavonic Translation in Mus}

The title of the translation in Mus transliterates Cant 1:1 and adds a Slavonic translation: Ширь гаширим ${ }^{37}$ ашир'ли шломо. Рекше: пьсни пьснем, иже

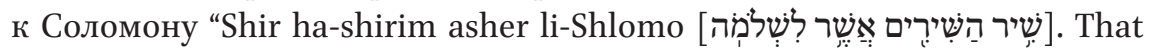
is, songs [plural instead of singular] of songs that are to [sc., of, a Semitism] Solomon". The plural form пьсни and the expected singular form пьснь are not similar enough to be easily confused.

33 S., beside Miller, "Epigraphical' Rabbis," especially A. Ovadiah, "Art of the Ancient Synagogues in Israel," in: Ancient Synagogues: Historical Analysis and Archaeological Discovery, eds. D. Urman and P.V.M. Flesher, 2 vols. (StPB, 47), Leiden, 1995, vol. 2, pp. 301-318; idem, "Conservative Approaches in the Ancient Synagogue Mosaic Pavements in Israel: The Cases of 'Eyn Gedi and Sepphoris/Zippori," Gerión, 28 (2011), pp. 43-55; M. Avi-Yonah, Art in Ancient Palestine: Selected Studies, eds. H. Katzenstein and Y. Tsafrir, Jerusalem, 1981 (several 1970s papers on the pavements in the ancient synagogues and the Zodiacs); R. Hachlili, "The Zodiac in Ancient Jewish Synagogal Art: A Review," JsQ, 9 (2002), pp. 219258; eadem, Ancient Synagogues - Archaeology and Art: New Discoveries and Current Research (Ho Section 1, 105), Leiden, 2013, pp. 339-388 (ch. VII: The Jewish Calendar Represented in the Zodiac Design); Y. Englard, "Mosaic as Midrash:The Zodiacs of the Ancient Synagogues and the Conflict between Judaism and Christianity," Review of Rabbinic Judaism, 6 (2003), pp. 189-214.

34 Cf. M. Goodman, "The Jewish Image of God in the Late Antiquity," in: Jewish Culture and Society under the Christian Roman Empire, eds. R. Kalmin and S. Schwartz, Leuven, 2003, pp. 133-145. Reprinted in M. Goodman, Judaism in the Roman World: Collected Essays (Ancient Judaism and Early Christianity, 66), Leiden, 2007, pp. 205-217.

35 Cf. J. Magness, "Heaven and Earth: Helios and Zodiac Cycle in Ancient Palestinian Synagogues," DOP, 59 (2005), pp. 1-52.

${ }_{3} 6$ Cf. S. Fine, "The Jewish Helios: A Modest Proposal Regarding the Sun God and the Zodiac on Late Antique Synagogue Mosaics," in his Art, History and the Historiography of Judaism in Roman Antiquity (Brill Reference Library of Judaism, 34), Leiden, 2014, pp. 161-180, who insists that all these images were fitting with the Rabbinic Judaism of the epoch. 
This title is considered by the Slavists among the proofs that the translated text is the standard one of the Hebrew (Masoretic) Bible, but we have demonstrated that the translated recension is sometimes different from the preserved Hebrew recension. Variant readings of the title with the plural "Songs" are known in a large part of the Greek manuscript and exegetical traditions, since the fourth-century Codex Alexandrinus ( $\ddot{\alpha} \sigma \mu \alpha \tau \alpha \tau \hat{\omega} \nu \dot{\alpha} \sigma \mu \dot{\alpha} \tau \omega \nu)$, and in the Aramaic Targum (שירין ותשבחן דאמר שלמה "The Songs and Praises which Solomon spoke...").

In Peshitta the title varies, but some variants preserve the Hebrew title (followed by a translation into Syriac), and this is only in the forms direr . Both phrases are apparently transliterations from $\mathrm{He}$ brew having no specific meaning in Syriac. However, the case is not as simple as that.

The transliterations use the Syriac marker of plural Syāmē (two dots above some letter of the word in plural). In the first case, the plural שירוֹת form the feminine שִירָיר used in the Masoretic text, whose meaning is the same) is intended; this word is to be pronounced as yod. It seems that the lack of Syāmē on the first component of ë̌x direx is an incidental omission made by Syriac scribes rather than a deliberate intention of rendering some other morphological derivate.

The second component of the Peshițta transliteration is certainly Aramaic, that is, שירין instead of the Hebrew plural שִיריר. One can suppose that at least some of the sources of the Peshitta readings, which do not always coincide with the known Hebrew and Greek texts, ${ }^{39}$ were Aramaic.

The Slavonic title of Mus, after having reproduced in transliteration the Hebrew one, goes back to the ancient tradition, where the Hebrew title was first transliterated and then translated into the language of the given version. Moreover, the words иже к Соломону, being a blatant Semitism - but not necessarily a Hebraism as it is treated by Slavists - are a demonstration that even this part of the title, already being a translation from Hebrew, is translated into Slavonic from a Semitic language. The plural from пьсни "songs" instead of the singular form just transliterated from Hebrew in the very same title in Slavonic would point to either an unknown Hebrew text (such as the

$38 \quad$ BDB, s.v.

39 P.B. Dirksen, "Septuagint and Peshitta in the Apparatus to Canticles in Biblia Hebraica Quinta," in Sôfer Mahîr: Essays in Honour of Adrian Schenker Offered by Editors of Biblia Hebraica Quinta, eds. Y. Goldman et al. (VTSup, 110), Leiden, 2006, pp. 15-31. 
hypothetical lost original of the Greek reading with plural) or a text in rabbinic Aramaic or Syriac.

The Slavonic title as a whole is certainly a direct translation from a Semitic language. However, the original Hebrew title is, in Slavonic, encapsulated within the transliteration, and the following translated title does not coincide with it. The only natural explanation of these phenomena is a supposition that the Slavonic title is translated from a Semitic title, which was in a language other than Hebrew and already contained a transliteration and a translation of the Hebrew title in slightly different forms. Similar titles in a Semitic language survived in Syriac in some manuscripts of Peshițta.

\section{Conclusion: the Textual Transmission}

The consensus opinion that Mus is translated directly from Hebrew is not as evident as one had thought.

First, the ultimate original of the Slavonic translation is not the Masoretic text but some other unknown recension, even though this recension is compatible with both Rabbinic and Second Temple period Judaism. It elaborates on the exegetical traditions that originated in the Second Temple period but have never completely disappeared from the rabbinical exegesis.

Nevertheless, the Slavonic title in Mus appeared as a translation from a Semitic text already translated from Hebrew. This is a weighty argument for the existence of an intermediary Semitic text between the Hebrew and the Slavonic.

Needless to say that the features of the Slavonic translation that, according to the widely held opinion of the Slavists, reveal an original in Hebrew could be equally interpreted as revealing an original in some other Northwest Semitic language, such as some dialect of Aramaic, either rabbinic or Syriac.

Moreover, the peculiar plural form in the Slavonic title, "songs of songs" instead of the singular "song of songs" is compatible with both Aramaic rabbinic Targum and Syriac Peshițta but not the Masoretic Hebrew text. This argument, however, is not decisive, because the presence of the plural variant in some manuscripts of the Greek version points, with a substantial likelihood, to the existence of such variant in Hebrew too. Nevertheless, the Hebrew title that is transliterated in our Slavonic text keeps the first word "song" in singular. Therefore, it is unlikely that the title of Mus goes back to an original in Hebrew and not in another Semitic language.

It is also of importance that one of the readings of Peshitta in 3:9 ("throne" instead of "palanquin") corroborates the recension of 3:9-10 in our Slavonic 
text, whereas the Hebrew and the other versions have completely different readings.

Far from being a translation of the Peshițta recension, our Slavonic text, however, reveals some specific proximity with the Aramaic in general and especially Syriac tradition.

Finally, let us add, the translations made directly from Syriac are known in the early Slavonic literature - for the texts unavailable in Greek. Our text is certainly absent in Greek. If the Slavonic translation is not Russian with South Slavic features but genuinely South Slavic, it could belong to the earliest period of Slavic writing. ${ }^{40}$

The balance of the probabilities ${ }^{41}$ points to the following historical scheme:

Mus ("westernised" recension of the South Slavic translation) $\uparrow$

*Early South Slavic translation

$\uparrow$

*Syriac recension

$\uparrow$

*Aramaic or Aramaised Jewish recension

$\uparrow$

Hebrew text (similar or identical to the Masoretic one).$^{42}$

40 Cf. Lourié, "Direct Translatins," with a bibliography.

41 This balance could be changed in a near future with new and still unpublished data by Alexander Grishchenko. He discovered one more folio of the Museum manuscript (overlooked by Alekseev) and, moreover, found some parallels in mediaeval Jewish exegesis in Yiddish. Anyway, the Jewish exegesis discussed above is ancient but another path of its tradition (through the Ashkenazim Jewish diaspora and western Slavic lands instead of a Syriac intermediary and a South Slavic Sitz im Leben of the Slavonic translation) is still not excluded. I am very grateful to Alexander Grishchenko for discussing with me his findings.

42 I would like to express my gratitude to Dr Camille Miller for improving my English. 